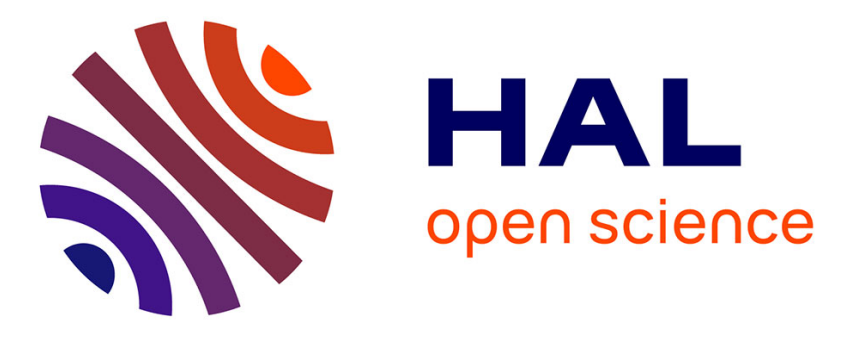

\title{
Comparative studies of three tropical wood species under compressive cyclic loading and moisture content changes
}

Arnauld Clauvy's Engonga Edzang, Claude Feldman Pambou Nziengui, Serge Ekomy Ango, Samuel Ikogou, Rostand Moutou Pitti

\section{To cite this version:}

Arnauld Clauvy's Engonga Edzang, Claude Feldman Pambou Nziengui, Serge Ekomy Ango, Samuel Ikogou, Rostand Moutou Pitti. Comparative studies of three tropical wood species under compressive cyclic loading and moisture content changes. Wood Material Science and Engineering, In press, 10.1080/17480272.2020.1712739 . hal-03034992

\section{HAL Id: hal-03034992 https://hal.science/hal-03034992}

Submitted on 1 Dec 2020

HAL is a multi-disciplinary open access archive for the deposit and dissemination of scientific research documents, whether they are published or not. The documents may come from teaching and research institutions in France or abroad, or from public or private research centers.
L'archive ouverte pluridisciplinaire HAL, est destinée au dépôt et à la diffusion de documents scientifiques de niveau recherche, publiés ou non, émanant des établissements d'enseignement et de recherche français ou étrangers, des laboratoires publics ou privés. 


\title{
Comparative studies of three tropical wood species under compressive cyclic loading and moisture content changes
}

\author{
Arnauld Clauvy's ENGONGA EDZANG ${ }^{1}$, Claude Feldman PAMBOU NZIENGUI ${ }^{1,2}$, Serge \\ EKOMY ANGO ${ }^{3}$, Samuel IKOGOU ${ }^{4}$, Rostand MOUTOU PITTI ${ }^{2,3}$, \\ ${ }^{1}$ Ecole Nationale des Eaux et Forêts, LaReVa Bois, BP 3960 Libreville, Gabon \\ ${ }^{2}$ Université Clermont Auvergne, CNRS, SIGMA Clermont, Institut Pascal, BP 10448, 63000 \\ Clermont-Ferrand, France \\ ${ }^{3}$ CENAREST, IRT, BP 14070, Libreville, Gabon \\ ${ }^{4}$ USTM, Ecole Polytechnique de Masuku, BP 901 Franceville, Gabon
}

\begin{abstract}
The objective of the present study is to perform an experimental comparative cyclic compressive loading test on three tropical species (Aucoumea Klaineana Pierre, Milicia Excelsa and Pterocarpus Soyauxii), at different internal moisture content stages. 150 samples of these three species, dimensioned according to standard NF EN 408 were tested. The specimens were loaded into the static compressive test until they collapsed in order to obtain the mechanical characteristics of each species in terms of: (i) the modulus of elasticity, (ii) the maximal strength and (iii) the stress at the yield point. The specimens are submitted five times to loading-unloading-reloading in cyclic compressive at different internal moisture contents. The applied force was taken at $10 \%$ of the maximum rupture force of Okoume species and kept constant at each cycle. The results show a stiffening of the three types of specimens with the loading cycles. The stiffening is faster from the densest species to the least dense species, respectively. In addition, the phenomenon of densification, that occurs during the five loading-unloading cycles, is done with constancy of compressive strength in the three species studied.
\end{abstract}

Keywords: Tropical species; internal humidity impact; cyclic compressive loading

\section{Nomenclature}

$\begin{array}{ll}\rho & \text { Density of specimen } \\ e & \text { Thickness of specimen } \\ \mathrm{h} & \text { Width of specimen } \\ \mathrm{L} & \text { Length of specimen } \\ M C(\%) & \text { Moisture Content } \\ F S P & \text { Fibre Saturation Point } \\ M O E & \text { Modulus of Elasticity } \\ \mathrm{MS} & \text { Maximum Stress } \\ \varepsilon_{\mathrm{s}} & \text { Strain amplitude } \\ \mathrm{M} & \text { Mass of specimen } \\ \mathrm{Mo} & \text { Anhydrous masses own } \\ \text { Moi } & \text { Intermediary anhydrous mass } \\ M_{H} & \text { Mass of the wet sample }\end{array}$




\section{Introduction}

Providing viable solutions to global warming is one of the major challenges of our century. As we know, one of the origins of climate change is the proliferation in the environment of non-ecological construction materials or tools such as steel and concrete. There is growing interest in the use of wood in the construction industry worldwide, particularly in European countries. This is valid both in so-called temperate regions, and so-called tropical regions. In Gabon, this involves the harvesting of new wood species. Indeed, Okoume or Aucoumea Klaineana Pierre has long been the only species harvested in Gabon. During the 20th century, its production continued to increase with the continuous improvement of machinery and the increased harvesting surface areas (Medzegue et al. 2007, Peyrot 2008). However, from the 1960s, we saw harvesting of new species of so-called diverse woods. Among these species we have: the Iroko or Milicia Excelsa and Padouk or Pterocarpus Soyauxii (Peyrot 2008, Mertens et al. 2007). These species, at 12\% moisture content, offer chemical and physical-mechanical properties superior to those of Okoume. Thus, for a better use of these species called diverse woods, it is necessary to study them under complex loading conditions.

Wood is a material whose mechanical properties (elastic, viscous, breakage...) are related to the conditions of variation of environmental parameters such as the relative moisture and temperature (Eurocode 1 2005, Moutee 2006, Gerhards 1982, Ebrahimzadeh and Kubat 1993). The mechanical properties of the wood material depend on the moisture content and dimensional changes induced by these moisture changes often result in significantly greater displacements than those caused by the mechanical loads (Mårtensson and Thelandersson 1990, Lenth and Kamke 2001, Moutee et al. 2005, Mukudai and Yata 1986, Navi and Girardet 2000). Also, the work of Gerhards (1982) show that many of the mechanical properties of wood reduce when its moisture content varies between $12 \%$ and $20 \%$, below the fibre saturation point (FSP). These results are also supported by Guitard et al. (1987), through its numerical model to calculate elastic properties, it shows the dependency of these parameters on moisture content variations. In addition, the interaction of moisture changes with mechanical loads can lead to excessive strains in wood structures (Redman et al. 2016, Manfoumbi Boussougou et al. 2014). By themselves, these two examples describe the influence of moisture on the behaviour of the wood material in structures sufficiently well.

The literature review shows that the stresses on wood materials and timber structures are mainly due to the combined impact of mechanical and environmental effects (Eurocode 1 2005, Moutee 2006, Eurocode 5 2005). In fact, there are very specific processes used to describe the laws of mechanical behaviour of materials in general and wood in particular in interaction with environmental factors. Among these processes, we have different tests such as creep, bending, traction, compression, torsion and shear tests. All these processes have the sole purpose of determining the relationships between the stresses and strains of the tested material. To these tests, we can add the cyclic tests, characterized by a mode of fatigue breakage which is just as important but rarely studied, especially on wood material (Pambou Nziengui et al. 2017, Nafa and Araar 2003), and even less so on tropical species. Also, Pambou and al (2017) through the study on the mechanical behaviour of Okoume under cyclic stress, have shown on the one hand that deterioration of Okoume is faster in cyclic compression than in static compression. On the other hand, they showed that the coupling of the number of loading cycles with the variation of the moisture content of Okoume amplifies the latter's loss of mechanical performance under a variable load. Nafa et al. (2003) worked on the damage to laminated timber beams submitted to cyclic torsional loading and showed the influence of the load level on the behaviour and durability of laminated timber beams. However, these studies alone are not enough to account for the behaviour of the wood material under cyclic stress, especially that of tropical woods in a variable environment. 
Moreover, when loading cyclically with a fairly low stress to a limited number of cyclics, densification occurs on the loaded material (Kutnar et al. 2008). During this densification, the cellular structure of the wood is permanently modified, giving a material with new properties (Blomberg and Persson 2004, Kutnar and Šernek 2007). One of the main factors influencing the mechanical and physical behaviour of densified wood is the amount and type of cell collapse. We are interested here in the environmental factors affecting the behaviour of densified wood, especially moisture. Our study therefore deals with the problem of the mechanical behaviour of tropical woods, subjected to the combined stress of cyclic mechanical loadings and changes in the internal moisture content of wood. The objective is to understand the behaviour in cyclic compressive testing of three tropical species, namely the Okoume, Iroko and Padouk. The first part of this article presents the experimental setup used, as well as the protocol adopted to conduct our study. The second part presents the results obtained during the experimental tests, namely: the results on the impact of the loading combined with moisture variations on the behaviour of our three species.

\section{Material and methods}

\section{Wood specimens}

Okoume, whose scientific name is Aucoumea klaineana Pierre, is a species in the Burseraceae family, which can be found in Gabon (from the coast to a line passing through Okondja in eastern Gabon and between Mitzic and Oyem in northern Gabon), Cameroon, Congo and over almost the whole Equatorial Guinea region (Medzegue 2007). Okoume is a fast-growing species that grows to a height of over $50 \mathrm{~m}$ and has a trunk diameter of up to $2 \mathrm{~m}$. In Gabon, it is used mainly for the manufacture of plywood, but also for structures such as sliced veneer and multi-ply plates (Martin and Vernay 2016, Gérard et al. 1998, Gérard et al. 2004).

The term "Iroko" refers to the two species of the genus Milicia in the Moraceae family: Milicia Excelsa and Milicia Regia, which are very similar in morphology. Milicia excelsa is generally found on the African continent, from Guinea Bissau to Ethiopia, to Angola and Zimbabwe in a southerly direction; it is found particularly in Gabon. This tree reaches a maximum height of 45 to $50 \mathrm{~m}$ with a diameter of about $2.5 \mathrm{~m}$. It was first used in Gabon for the construction of canoes, then for structures such as glued laminated posts and carpentry (Martin and Vernay 2016, Daïnou et al. 2012, Gérard et al. 1998).

Padouk of Africa is the commercial name of Pterocarpus Soyauxii Taub of the Fabaceae family, a species found in Central and West Africa but whose optimal growing area is Gabon and Cameroun. It is suitable for carving, cabinet making but also for hydraulic work in immersed marine environments and shipbuilding. Moreover, with its very interesting resonance properties (very pure metallic resonance), it is also perfectly suitable for the manufacture of organs, pianos or other musical instruments. Padouk trees reach a height of nearly $50 \mathrm{~m}$, with a diameter of about 60 to 100 $\mathrm{cm}$ and are free of branches up to about $30 \mathrm{~m}$ (Gérard et al. 1998, Martin and Vernay 2016, Gérard et al. 2004).

The choice of these three species is explained by the fact that in this study one of the objectives is to highlight the impact of density on the mechanical behaviour of the wood. Hence the choice of a very light wood (Okoume), a medium-heavy wood (Iroko) and a heavy wood (Padouk)

The Iroko and Padouk specimens used for our tests were taken in Libreville, from an open-air sawmill site, located between the Nkembo junction and the bus station interchange. On this site, a 3 $\mathrm{m}$ Padouk batten and a $2.5 \mathrm{~m}$ Iroko board were purchased for our work. As for the Okoume samples (Figure 2.4), they were taken from the sample stock of the Laboratoire de Recherche et Valorisation du Matériau Bois (LaReVa Bois) at the Ecole Nationale des Eaux et Forêts (ENEF).

\section{Type of specimens used}


The dimensions of the wood specimens for the three species used (Fig. 1) are those given by the French standard NF EN 408 for a compression test, i.e. $20 \times 20 \times 60 \mathrm{~mm}^{3}$. A total of 240 test pieces were obtained, with 80 specimens per species. However, we only had to use 174 specimens, i.e. 58 per wood species.

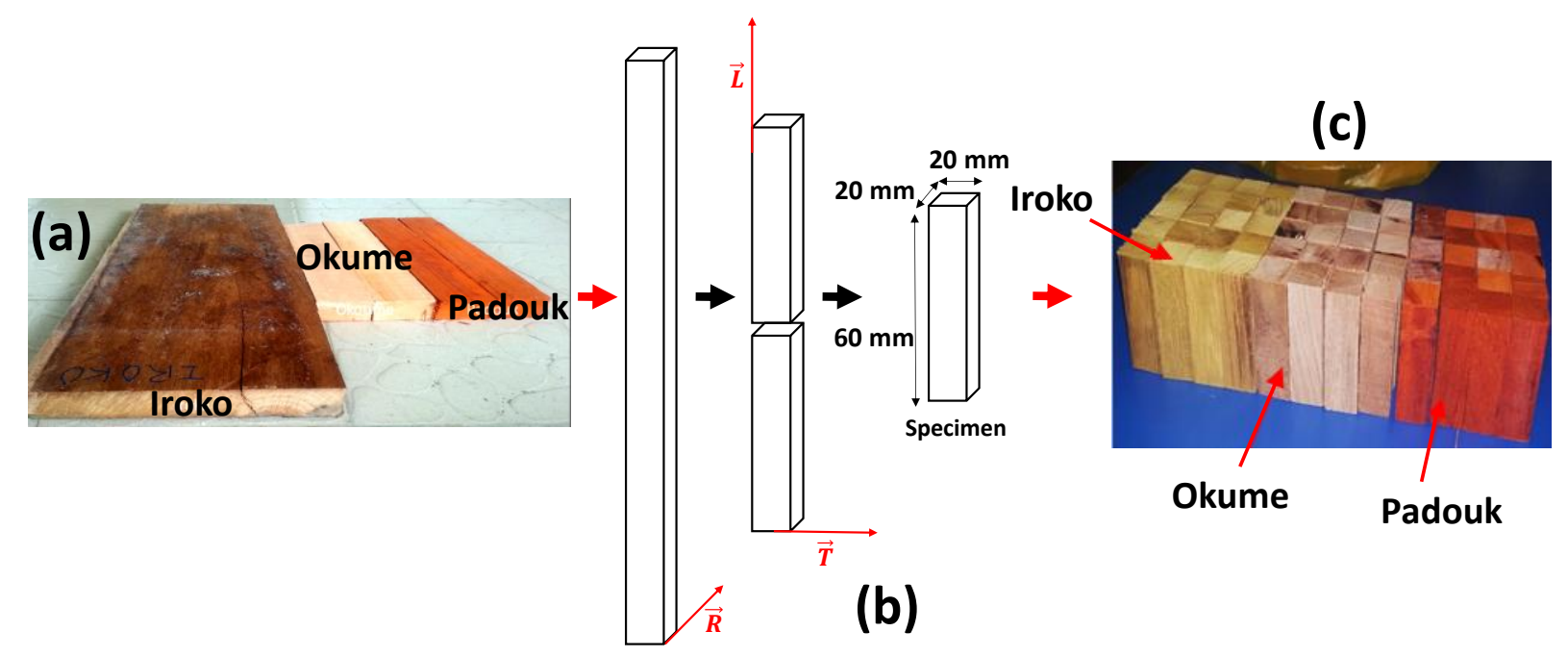

Figure 1. (a) Specimens of the species used, (b) general geometric configuration of test specimens; (c) specimens of the three topical species used.

\section{Sample preparation}

The experimental device is a combination of a "United testing systems machine" press, with a maximum load capacity of $100 \mathrm{kN}$ and a computer equipped with a data acquisition system managed by the Datum 5.0 software. To humidify the specimens, we used tanks filled with water, in which the specimens were immersed.

\section{Determining the intermediate dried weight $\left(M_{o i}\right)$}

Firstly, an intermediate dried weight $\left(M_{o i}\right)$ was determined for each group of species and for all the specimens. This $M_{o i}$ is considered as the own dried weight of the specimen. Five specimens of each group of species were selected, for a total of 15 specimens and put in an oven set to be dried at a temperature of $103^{\circ} \mathrm{C}$ (Odounga et al. 2018). Before they were dried by the oven, the starting weight of each sample was determined at time $t=0$.

Then, in order to monitor changes to their respective weights in the oven, their weights were measured on a weighing scales at 6 hour intervals until the weights stabilized. Figure 2 shows the changes during oven drying to the average weight of the species measured over time until the weights stabilized. There is a very rapid decrease in the weight of the specimens of all three species after 6 hours of drying. This decrease corresponds to a loss of moisture in the specimens (Moutee 2006, Moyne and Martin 1982). The dry weight is reached when a stabilization (linear part of the curves of Figure 2) of the sample weight is observed. Compared to Okume and Iroko, the dry weight of the Padouk is much higher due to its very high density. In addition, since Okoume and Iroko have rather similar densities, their dry weights seem similar. 


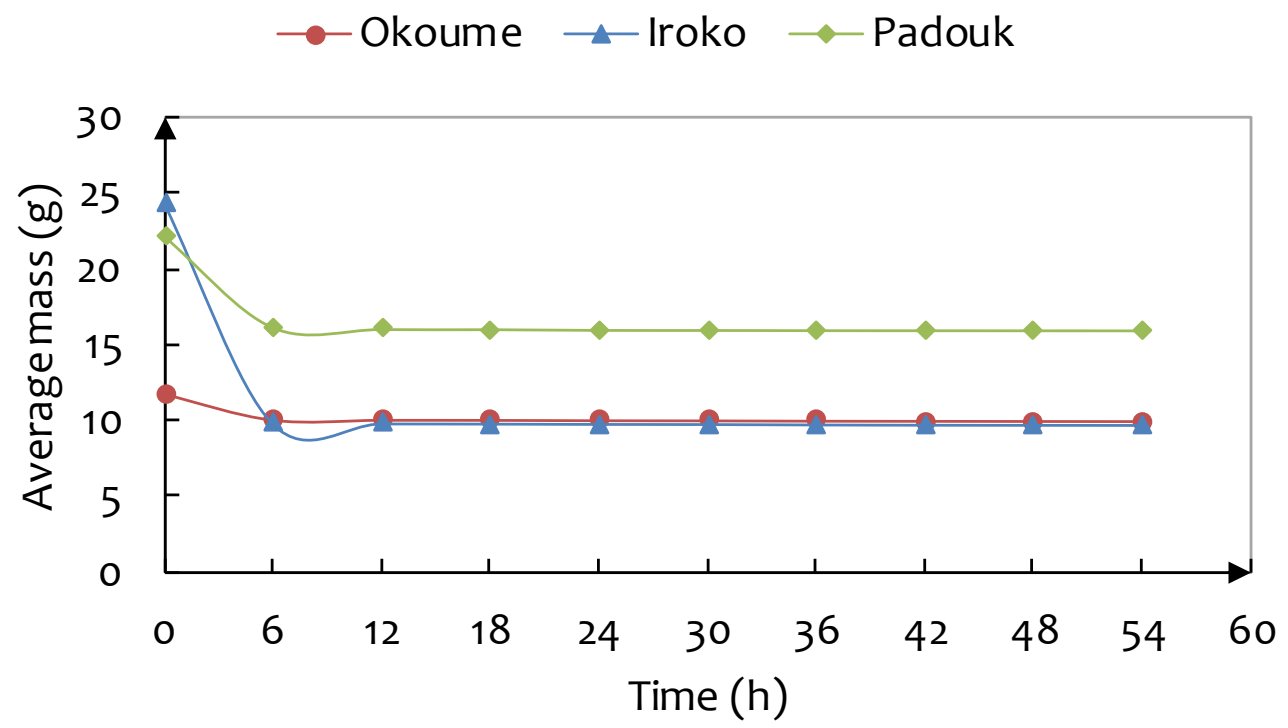

Figure 2. Changes to the average mass of the three species up to stabilisation

The weight value of the specimen, after it has stabilised in the oven, represents the own dried weight of the specimen. Finally, the intermediate dried weight (Moi) of each species, which will be used to determine the MC, was obtained by calculated the average dried weight of the five specimens using the following Equation:

$$
\text { Moi } \quad\left(\sum_{j=1}^{5} M o_{j}\right) / 5
$$

The results obtained from this calculation are shown in table 1 below.

Table 1. Intermediate anhydrous weight of the specimens

\begin{tabular}{lccc}
\hline Specimens & Okoume & Iroko & Padouk \\
\hline Spe 1 & 9.6829 & 9.5512 & 14.4766 \\
Spe 2 & 10.4028 & 9.5586 & 18.0570 \\
Spe 3 & 9.7914 & 10.2745 & 16.2674 \\
Spe 4 & 9.8849 & 9.1987 & 15.4956 \\
Spe 5 & 9.7829 & 9.6924 & 15.1801 \\
\hline \hline $\mathrm{M}_{\text {oi }}$ & 9.9090 & 9.6551 & 15.8953 \\
\hline
\end{tabular}

\section{Determining the moisture content (MC) of the specimen}

In this study eight different levels of Moisture Content (MC) for the specimens were chosen: 10\%, $15 \%, 25 \%, 30 \%, 35 \%, 40 \%, 60 \%$ and $90 \%$. To have these different levels of MC for each specimen, they were firstly put in tanks filled with water for saturation for six weeks for the Okoume and Iroko specimens and eight weeks for the Padouk specimens. Then, the results of the Moi (see table 1) calculated for each species were used to determine the moisture content (MC) of each specimen studied by combining the empirical method of MC determination and the Moi values for each species using the following equation: 


$$
\operatorname{MC}(\%)=\left[\left(M_{H}-M_{0 i}\right) / M_{0 i}\right] \times 100
$$

Where: $\mathrm{M}_{\mathrm{H}}$ is the weight of the wet sample and $M_{o i}$ the intermediate dried weight for each species.

\section{Results and discussions}

\section{Static compression loading}

Static compression tests were first performed on 5 specimens for each species to mechanically characterise them. Thus, by using these tests, we were able to determine the maximum stress at the collapse point and the modulus of elasticity (MOE) of each species for the static compressive test. Figure 3 shows the change in the relationships between the stresses and deformations of the Okoume (Figure 3a), Iroko (Figure 3b) and Padouk (Figure 3c) specimens in static compression at $12 \pm 2 \% \mathrm{MC}$.

According to the literature, two main sections can be identified on these stress-strain curves, i.e.: a linear part corresponding to the elastic zone and a parabolic shaped part corresponding to the plastic zone (Figure 3). The analysis of the different curves obtained during these static compression tests enabled us to determine the mechanical properties of our three species.
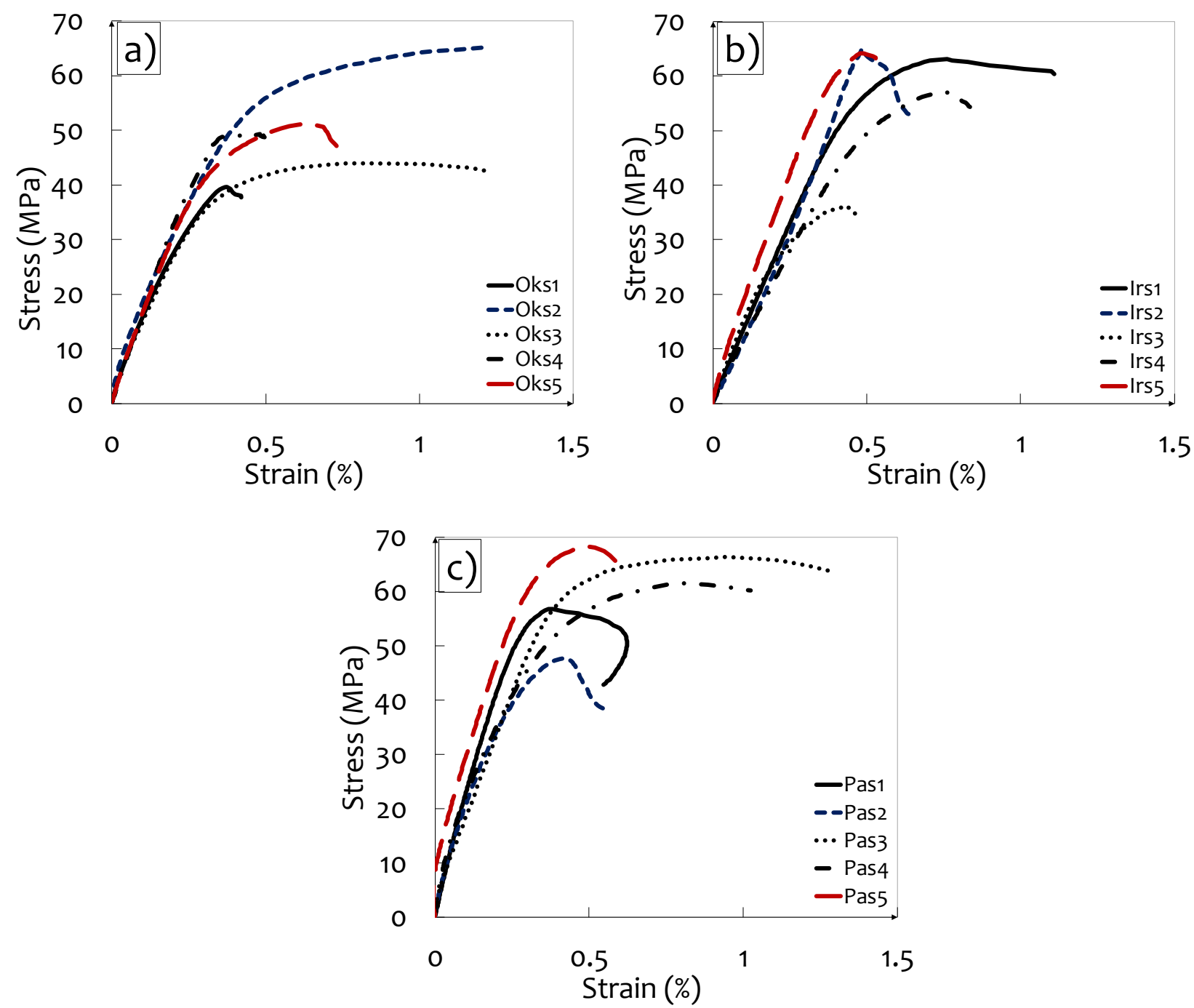

Figure 3. Typical stress-strain curves of static compression tests for the specimens: (a) Okoume, (b) Iroko and (c) Padouk 
Tables 2, 3 and 4 show the main physical and mechanical parameters of our three species for the five tests performed

Table 2. Physical and mechanical parameters of Okoume

\begin{tabular}{|c|c|c|c|c|c|c|c|c|}
\hline \multirow{2}{*}{ Specimens } & \multicolumn{3}{|c|}{ Size $(\mathrm{mm})$} & \multirow{2}{*}{$\begin{array}{r}\mathrm{MC} \\
(\%)\end{array}$} & \multirow{2}{*}{$\begin{array}{l}M \\
(g)\end{array}$} & \multirow{2}{*}{$\begin{array}{c}\rho \\
\left(\mathrm{kg} / \mathrm{m}^{3}\right)\end{array}$} & \multirow{2}{*}{$\begin{array}{l}\text { MOE } \\
(\mathrm{MPa})\end{array}$} & \multirow{2}{*}{$\begin{array}{c}\mathrm{MS} \\
(\mathrm{MPa})\end{array}$} \\
\hline & $\mathrm{L}$ & $\mathrm{e}_{\text {moy }}$ & $\mathrm{h}_{\text {moy }}$ & & & & & \\
\hline $\mathrm{Oks}_{1}$ & 61.38 & 20.22 & 19.52 & 12.2 & 11.120 & 0.459 & 8464.56 & 38.35 \\
\hline $\mathrm{Oks}_{2}$ & 61.28 & 19.79 & 19.67 & 12.8 & 11.177 & 0.469 & 14105.43 & 63.81 \\
\hline $\mathrm{Oks}_{3}$ & 60.70 & 19.61 & 19.61 & 12.5 & 11.146 & 0.478 & 12881.18 & 44.01 \\
\hline $\mathrm{Oks}_{4}$ & 61.45 & 19.73 & 19.70 & 12.6 & 11.159 & 0.467 & 13734.36 & 49.28 \\
\hline $\mathrm{Oks}_{5}$ & 61.81 & 19.78 & 19.31 & 12.2 & 11.113 & 0.471 & 14685.61 & 51.31 \\
\hline
\end{tabular}

Table 2. Physical and mechanical parameters of Iroko

\begin{tabular}{|c|c|c|c|c|c|c|c|c|}
\hline \multirow{2}{*}{ Specimens } & \multicolumn{3}{|c|}{ Size $(\mathrm{mm})$} & \multirow{2}{*}{$\begin{array}{l}\mathrm{MC} \\
(\%)\end{array}$} & \multirow{2}{*}{$\begin{array}{l}M \\
(\mathrm{~g})\end{array}$} & \multirow{2}{*}{$\begin{array}{c}\rho \\
\left(\mathrm{kg} / \mathrm{m}^{3}\right)\end{array}$} & \multirow{2}{*}{$\begin{array}{c}\mathrm{MOE} \\
(\mathrm{MPa})\end{array}$} & \multirow{2}{*}{$\begin{array}{c}\mathrm{MS} \\
(\mathrm{MPa})\end{array}$} \\
\hline & $\mathrm{L}$ & $\mathrm{e}_{\text {moy }}$ & $\mathrm{h}_{\text {moy }}$ & & & & & \\
\hline $\mathrm{Irs}_{4}$ & 60.79 & 19.54 & 19.09 & 13.06 & 10.916 & 0.482 & 12968.65 & 63.17 \\
\hline $\mathrm{Irs}_{2}$ & 60.88 & 19.39 & 19.40 & 11.08 & 10.725 & 0.468 & 12553.06 & 64.90 \\
\hline $\mathrm{Irs}_{3}$ & 60.83 & 19.38 & 19.27 & 12.80 & 10.891 & 0.479 & 14772.57 & 36.13 \\
\hline $\operatorname{Irs}_{5}$ & 60.80 & 19.49 & 19.33 & 11.47 & 10.762 & 0.470 & 10815.78 & 57.07 \\
\hline $\operatorname{Irs}_{1}$ & 60.94 & 19.65 & 19.56 & 12.53 & 10.865 & 0.464 & 14352.90 & 64.22 \\
\hline
\end{tabular}

Table 4. Physical and mechanical parameters of Padouk

\begin{tabular}{|c|c|c|c|c|c|c|c|c|}
\hline \multirow{2}{*}{ Specimens } & \multicolumn{3}{|c|}{ Size $(\mathrm{mm})$} & \multirow{2}{*}{$\begin{array}{l}\mathrm{MC} \\
(\%)\end{array}$} & \multirow{2}{*}{$\begin{array}{l}M \\
(g)\end{array}$} & \multirow{2}{*}{$\begin{array}{c}\rho \\
\left(\mathrm{kg} / \mathrm{m}^{3}\right)\end{array}$} & \multirow{2}{*}{$\begin{array}{l}\text { MOE } \\
(\mathrm{MPa})\end{array}$} & \multirow{2}{*}{$\begin{array}{c}\mathrm{MS} \\
(\mathrm{MPa})\end{array}$} \\
\hline & $\mathrm{L}$ & $\mathrm{e}_{\mathrm{moy}}$ & $\mathrm{h}_{\text {moy }}$ & & & & & \\
\hline $\mathrm{Pas}_{1}$ & 61.29 & 19.73 & 20.56 & 12.2 & 17.833 & 0.717 & 15321.28 & 56.46 \\
\hline $\mathrm{Pas}_{2}$ & 61.61 & 20.18 & 19.62 & 12.3 & 17.846 & 0.731 & 18841.60 & 47.68 \\
\hline $\mathrm{Pas}_{3}$ & 60.99 & 19.53 & 19.74 & 12.4 & 17.871 & 0.760 & 15020.71 & 66.35 \\
\hline $\mathrm{Pas}_{4}$ & 61.65 & 19.57 & 20.14 & 12.2 & 17.834 & 0.734 & 17930.03 & 61.51 \\
\hline $\mathrm{Pas}_{5}$ & 61.73 & 20.20 & 20.46 & 11.8 & 17.776 & 0.697 & 20327.38 & 68.37 \\
\hline
\end{tabular}


Table 5 below, shows the average modulus of elasticity (MOE) values and the maximum stress (MS).

Table 3. Average of the mechanical characteristics obtained for each species in static compression of Iroko, Okoume and Padouk

\begin{tabular}{lcc}
\hline Parameter & $\begin{array}{c}\text { MOE } \\
(\mathrm{MPa})\end{array}$ & $\begin{array}{c}\text { MS } \\
(\mathrm{MPa})\end{array}$ \\
\hline Okoume & $12774 \pm 2496.599$ & $49.35 \pm 9.519$ \\
Iroko & $13093 \pm 1573.295$ & $57.10 \pm 12.126$ \\
Padouk & $17488 \pm 2284.289$ & $60.07 \pm 8.321$ \\
\hline
\end{tabular}

As expected, we see in Table 1 that Padouk is the species that has the highest maximum stress at break point in static compression, followed respectively by Iroko and Okoume. This is easily explained by their respective densities. Padouk being the densest species with $0.728 \pm 0.023$ of density, its maximum stress at break point is therefore the highest, followed respectively by Iroko and Okoume (with respective densities of $0.474 \pm 0.021$ and $0.469 \pm 0.007$ ). This observation is also valid for the modulus of elasticity, Padouk still having the highest MOE value, followed by Iroko and Okoume.

The MOE values obtained experimentally differ from those obtained in the literature (Gérard et al. 2004, Gérard et al. 1998) by 23\%, $2 \%$ and $7 \%$ respectively for the Okoume, Iroko and Padouk specimens. Likewise, the maximum stresses differs by $27 \%, 5 \%$ and $8 \%$ respectively for the Okoume, Iroko and Padouk specimens. These differences between our experimental values and those from the literature can be explained in part by the origin of the species from which the specimens were taken. Indeed, several studies have shown that depending on their biological origins, the characteristics of wood materials can vary between species, within the same species and within the same tree (Medzegue et al. 2007, Pâques 1996, Guitard and Gachet 2004, Almeida 2006, Charron et al. 2003).

\section{Cyclic compression loading}

For each species studied, five compression loading cycles parallel to the fibres at a constant stress level (i.e. $10 \%$ of the maximum stress at the Okoume break point) were carried out. Figure 4 shows the general behaviour of the stress-strain curves of for the Okoume, Iroko and Padouk specimens obtained after the cyclic compression tests, at $10 \%$ of MC (Fig. 6a), $25 \%$ of MC (Figure $4 \mathrm{~b}$ ), $30 \%$ of MC (Figure 4c) and 60\% of MC (Figure 4d). It appears at each MC level of the specimens, that for the three species, the loading path differs from the unloading path. In other words, Okoume, Iroko and Padouk present hysteresis at unloading during the different cycles. These hysteresis phenomena can be explained by the fact that our materials are not perfectly elastic (Fozao et al. 2014). We also observe on these curves (Figure 4) that after the first loading cycle, the strain does not return to its initial position after the unloading path. This highlights the existence of the residual permanent strain that appeared in the first loading cycle, despite the low intensity of the force used (Pambou Nziengui et al. 2017). However, the residual permanent strain observed during the first loading cycle remains constant in the following cycles. Everything happens as if the specimen had adapted to the stress exerted. 

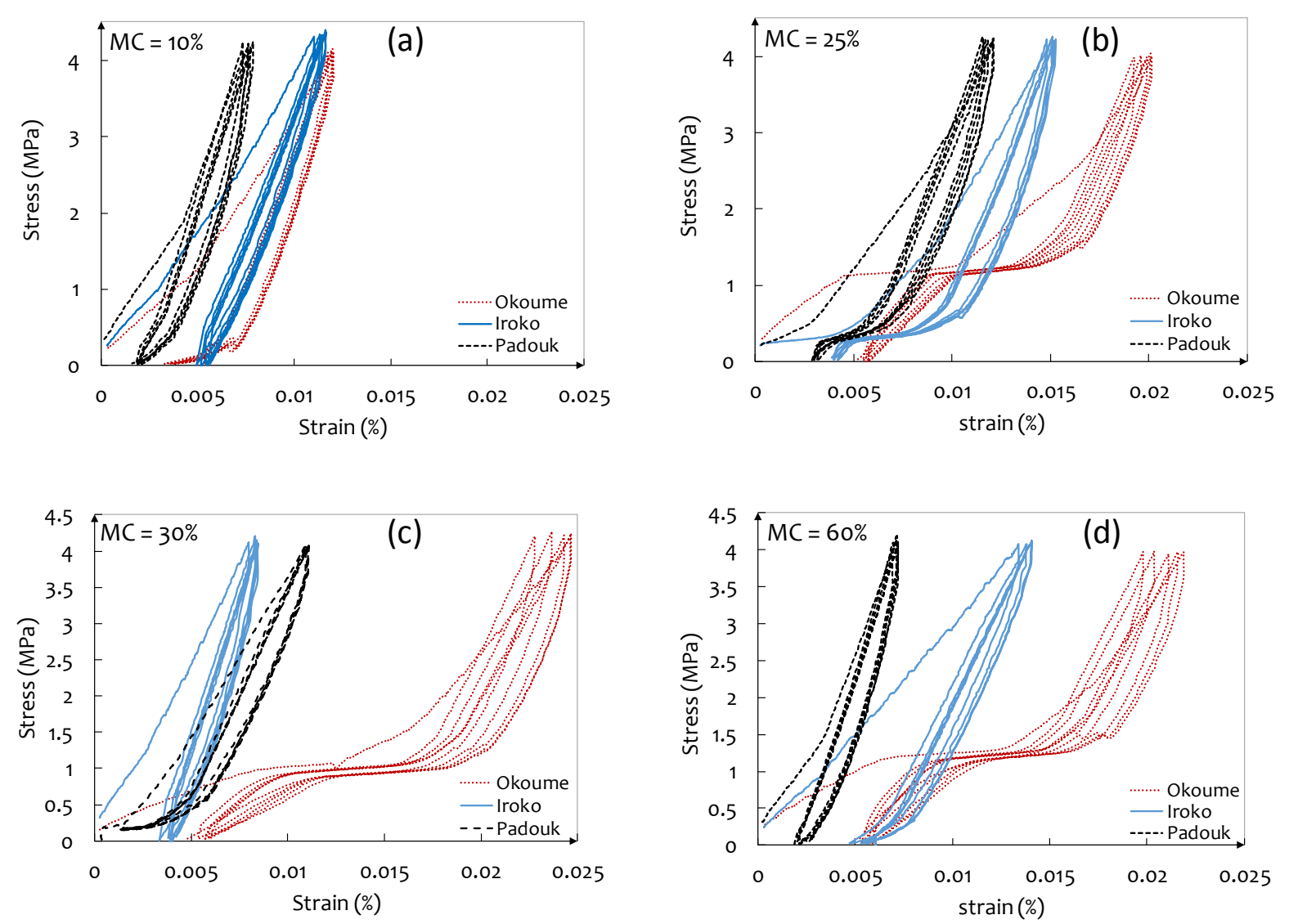

Figure 4. Typical stress-strain curves of cyclic compression specimens

\section{Impact of loading combined with variations in moisture content $(M C)$ on strain amplitude}

The histograms in Figure 5 show the change in deformation of the specimen after each cycle at different MC levels.

A closer observation of the stress-strain curves in Figure 4 shows a decrease in the strain amplitude $\left(\varepsilon_{\mathrm{s}}\right)$ with the number of loading cycles. Between the first and fifth loading cycles, a regression of $\varepsilon_{\mathrm{s}}$ of $0.11 \%, 0.10 \%$ and $0.05 \%$ for the Okoume, Iroko and Padouk respectively at $10 \%$ moisture (Figure 5a). At 25\% moisture (Figure 5b), the regression is $0.16 \%, 0.12 \%$ and $0.08 \%$ for the Okoume, Iroko and Padouk respectively. At $30 \%$ moisture (Figure 5c), it is $0.12 \%, 0.07 \%$ and $0.08 \%$ for the Okoume, Iroko and Padouk respectively. Finally, at $60 \%$ moisture (Figure 5d), the regression is $0.08 \%$ for the Okoume and Iroko, $0.06 \%$ for the Padouk. In other words, there is specimen strain during the loading cycle despite the low intensity of the load used. This explains the permanent strains that we observe on the curves in figure 5. This regression of $\varepsilon_{\mathrm{s}}$ can be explained by the densification phenomenon that appears during the different loading cycles (Kutnar et al. 2015, Blomberg and Persson 2004). Indeed, just as in the drying process, the cell wall is compacted and the mass of the ligneous substance in a given volume increases during the different loading cycles (Kutnar et al. 2015, Segovia et al. 2013). This has the consequence of stiffening the specimens and thus reducing the strain in the following cycles. Also, the change in behaviour between the Iroko and Padouk specimens observed in the second loading cycle (Figures 4a, 4b, 4c, 4d) suggests that the densification observed occurs earlier in the Padouk specimens compared to the Iroko specimens. 
This regression of the strain amplitude can also be explained by the accommodation effect (Nguyen 2014). Indeed, after the first loading cycle, we have the specimen adapts to the stress imposed which can cause the stabilization of the strain observed in the following cycles. The difference in behaviour between the Iroko and Padouk specimens from the second loading cycle suggests that the stabilisation of $\varepsilon_{\mathrm{s}}$ is quicker among the Padouk specimens compared to the other two species.

(a)

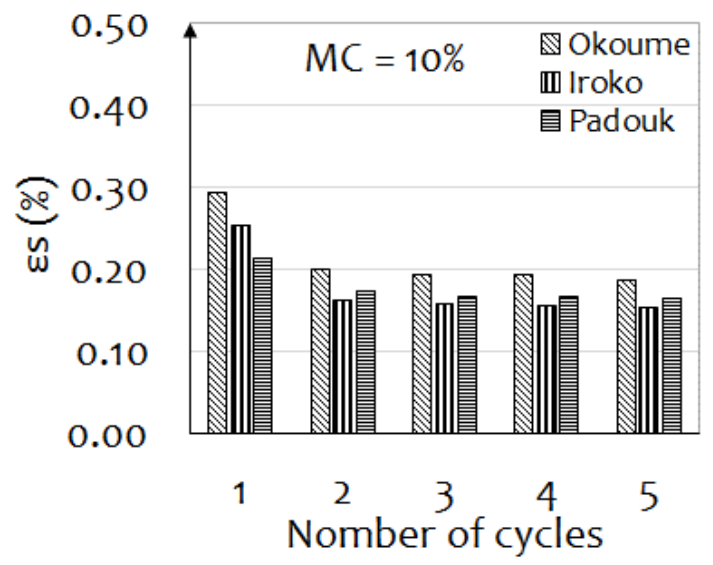

(c)

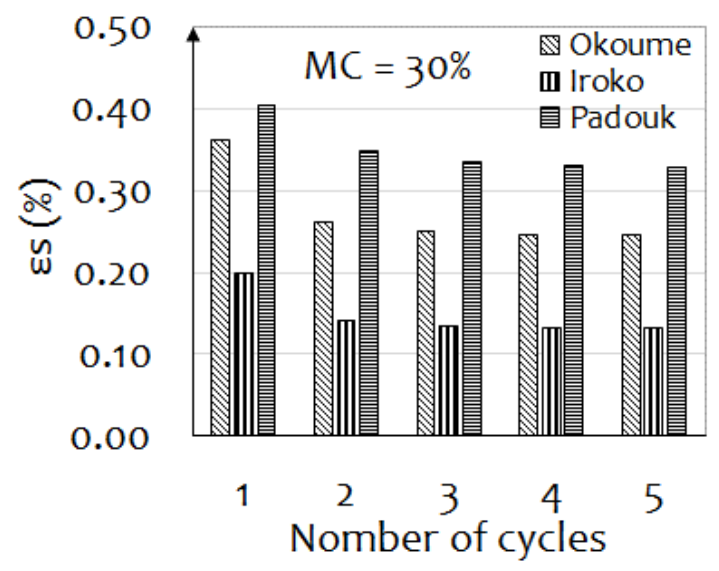

(b)

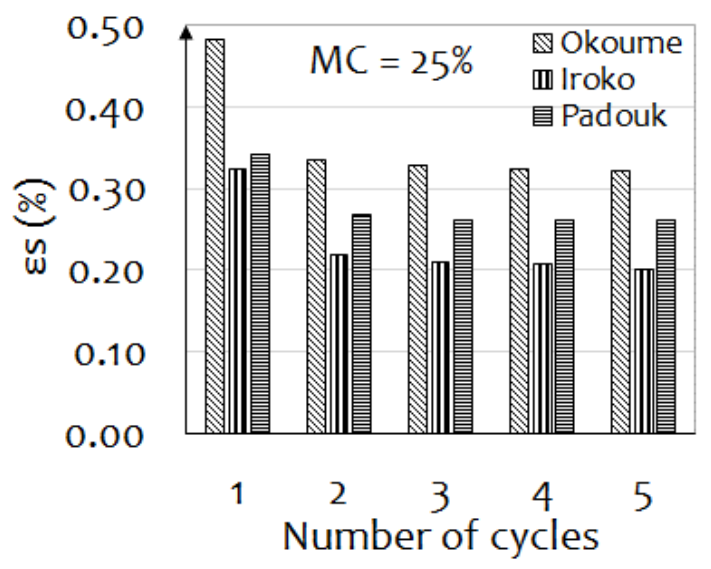

(d)

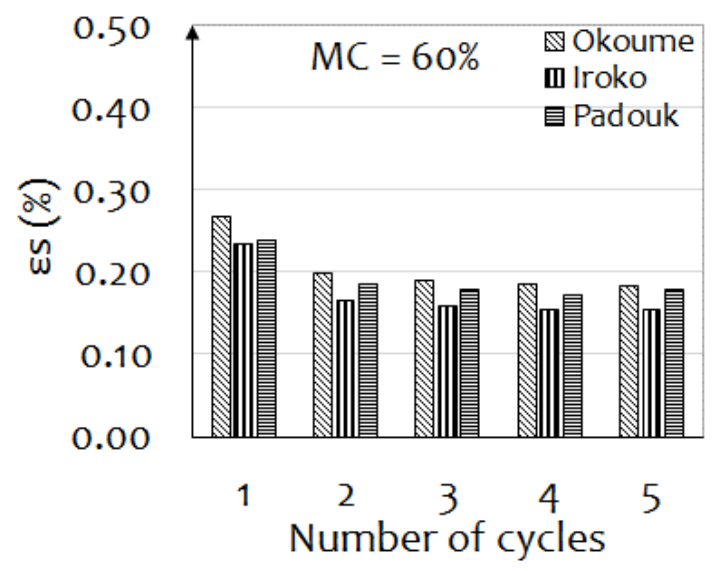

Figure 5. Comparison of the amplitudes of strain of the five loading cycles on the Okoume, Iroko and Padouk specimens 
For each cycle, we have traced the changes to the strain amplitude with different moisture levels. Figure 6 shows the change in $\varepsilon_{\mathrm{s}}$ at each loading cycle as a function of each moisture level for the
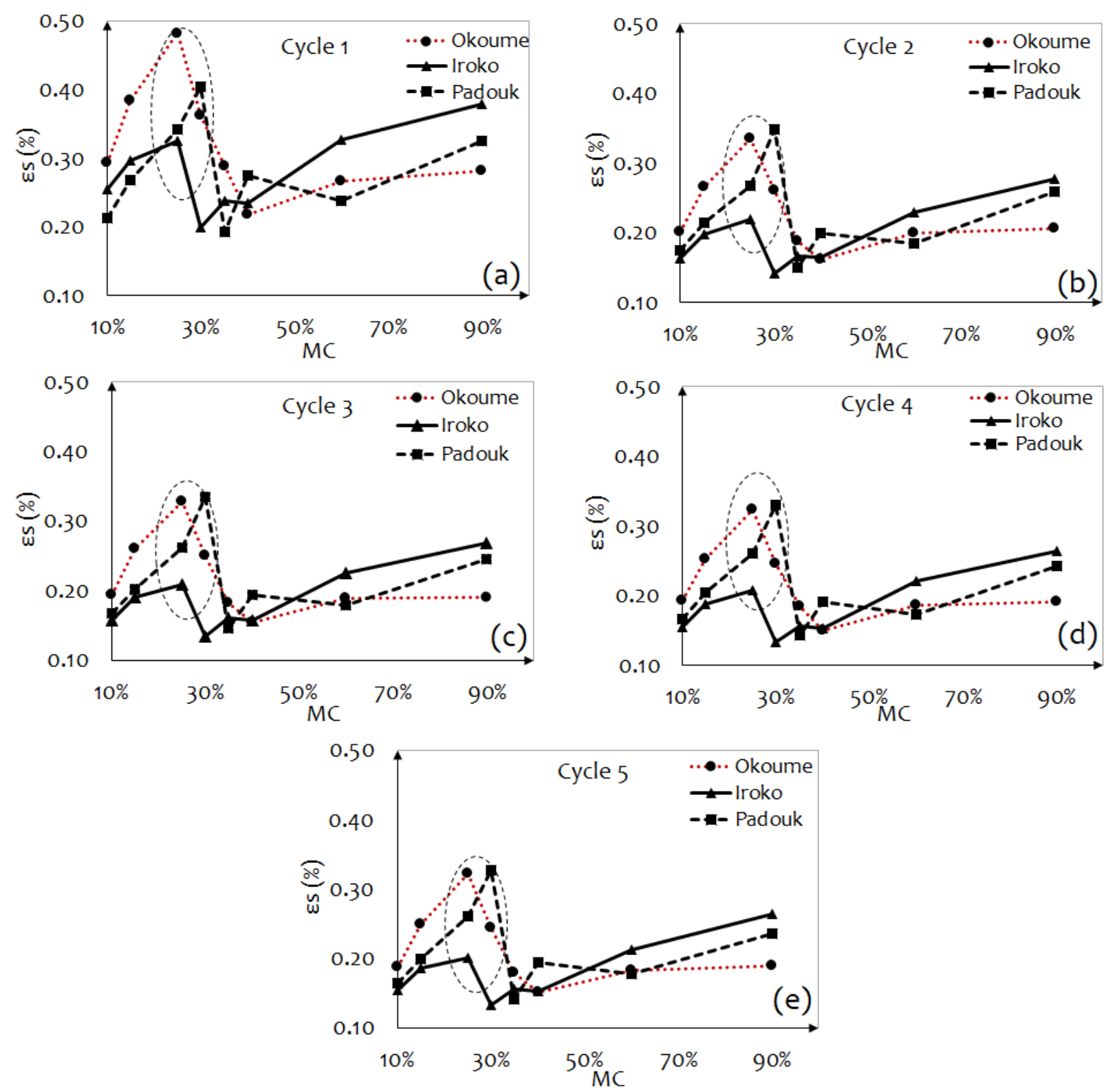

specimens tested.

Figure 6. Changes in strain amplitude $\left(\varepsilon_{\mathrm{s}}\right)$ for the Iroko, Okoume and Padouk specimens according to the moisture levels. The ellipses represent the hygroscopic domain of our three species.

In general, for the three species studied, we observed an increase in strain amplitude at each cycle up to a certain moisture level close to $30 \%$ (Figures $6 \mathrm{a}, 6 \mathrm{~b}, 6 \mathrm{c}, 6 \mathrm{~d}$, and $6 \mathrm{e}$ ). This increase in $\varepsilon_{\mathrm{s}}$ as moisture levels rose can be explained by the softening of the test pieces due to the increase in the moisture content. Indeed, the change in moisture content deeply affects the balance of the elastic constants of the wood, especially where the moisture content is in the hygroscopic domain (Dinh 2011, Gerhards 1982, Moutee et al. 2005). Thus, the increase in humidity causes a decrease in the rigidity of the specimens. This decrease in the rigidity has the effect of increasing the specimen strains during loading. However, Figure 7 also shows that the increase in strain as with moisture levels rise is not continuous. There is a discontinuity due to the FSP, the point from which the MC level becomes too large to judge the effect of the stress. It is therefore more than likely that the area where this change of variation occurs matches the hygroscopic domain of our three species. The 
ellipse observed on each of the curves in Figure 7 thus shows the hygroscopic domain. Finally, it should be said that these results are fairly consistent with the data in the literature, which indicates PSF at around 30\%, 25\% and 21\% moisture respectively for the Okoume, Iroko and Padouk specimens (Gérard et al. 2004, Gérard et al. 1998, Medzegue et al. 2007).

\section{Conclusion}

The objective of this study was to perform a comparative study to highlight the impact of cyclic compressive loading combined with variations in moisture content, on the mechanical behaviour of 3 tropical species. Three wood species were chosen including a very soft wood (Okoume), a medium hardwood (Iroko) and a very hard wood (Padouk). The dimensions of the wood specimens for the three species used are those set down in French standard NF EN 408 for a compression test, i.e. $20 \times 20 \times 60 \mathrm{~mm}$.

The cyclic tests carried out (in the elastic domain) made it possible, firstly, to highlight the emergence of a constant residual permanent strain in the specimens of the three species during the different loading cycles. In other words, the strains generated during the loading are not fully absorbed when unloaded. Hysteresis is then observed during unloading. On the other hand, these cyclic tests carried out with a constant load level and at different moisture levels made it possible to show that there is a densification of the specimens which occurs with the loading cycles, thus causing the regression of the strain. In addition, they show that the densification observed is faster respectively from the densest species (Padouk) to the least dense species (Iroko and Okoume respectively) in the dry state (here at $10 \%$ of $\mathrm{MC}$ ). This trend tends to change in the hygrometric domain where the impact of moisture content coupled with loading becomes less and less important.

For future work, in order to better evaluate the resistance of our three species subjected to cyclic stress in compression; it would be interesting to increase the number of loading cycles. In other words, it would be interesting to also perform fatigue tests in compression. It would also be interesting to perform cyclic bending tests to understand the behaviour of structures such as bridges.

\section{Acknowledgments}

The authors wish to thank the Network of Forestry and Environmental Training Institutions of Central Africa (RIFFEAC) for the implementation of the Wood Science Master of the Ecole Nationale des Eaux et Forêts (ENEF - GABON) as well as the PEPS project CNRS "RUMO" and the Auvergne Rhône-Alpes Region (AURA) for financial support under the SCUSI project.

\section{References}

Almeida, G. (2006) Influence de la structure du bois sur ses propriétés physico-mécaniques à des teneurs en humidité élevées, unpublished thesis Univerté Laval.

Blomberg, J. and Persson, B. (2004) 'Plastic deformation in small clear pieces of Scots pine (Pinus sylvestris) during densification with the CaLignum process', Journal of Wood Science, 50(4), 307-314.

Charron, S., Jourez, B., Marchal, M. and Hébert, J. (2003) 'Etude comparative des caractéristiques physiques et mécaniques du bois des mélèzes d'Europe (Larix decidua Mill.), du Japon (Larix kaempferi (Lambert) Carr.) et de leur hybride (Larix x eurolepis Henry)', Biotechnologie, Agronomie, Société et Environnement, 7(1), 5-16.

Daïnou, K., Doucet, J.-L., Sinsin, B. and Mahy, G. (2012) 'Identité et écologie des espèces forestières commerciales d'Afrique centrale: le cas de Milicia spp.(synthèse bibliographique)', Biotechnologie, Agronomie, Société et Environnement, 16(2), 229-241. 
Dinh, A. T. (2011) Linear elastic and non-linear behaviour of wood according to its structure, unpublished thesis AgroParisTech.

Ebrahimzadeh, P. and Kubat, D. (1993) 'Effects of humidity changes on damping and stress relaxation in wood', Journal of materials science, 28(20), 5668-5674.

Eurocode 1, A. (2005) Eurocode 1: Actions sur les structures-Partie 1-4: Actions généralesActions du vent, EN 1991-1-4.

Eurocode 5, A. (2005) '5: Conception et calcul des structures en bois-Partie 1-1: GénéralitésRègles communes et règles pour les bâtiments', Norme française NF EN 1995-1, 1.

Fozao, D. S., Foudjet, A., A, K. and D, F. (2014) Modeling the stress-strain behavior of Bamboo under cyclic uniaxial loading.

Gérard, J., Beauchêne, J., Fouquet, D., Guibal, D., Langbour, P., Thévenon, M.-F., Thibaut, A. and Vernay, M. (2004) TROPIX 5.0 : caractéristiques technologiques de 215 essences tropicales, email to [accessed none].

Gérard, J., Edi Kouassi, A., Daigremont, C., Détienne, P., Fouquet, D. and Vernay, M. (1998) Synthèse sur les caractéristiques technologiques de référence des principaux bois commerciaux africains, Série FORAFRI, Montpellier, France: CIRAD-Forêt.

Gerhards, C. C. (1982) 'Effect of moisture content and temperature on the mechanical properties of wood: an analysis of immediate effects', Wood and Fiber Science, 14(1), 4-36.

Guitard, D. and Gachet, C. (2004) 'Paramètres structuraux et/ou ultrastructuraux facteurs de la variabilité intra-arbre de l'anisotropie élastique du bois', Ann. For. Sci., 61(2), 129-139.

Kutnar, A., Kamke, F. A. and Sernek, M. (2008) 'The mechanical properties of densified VTC wood relevant for structural composites', Holz als Roh-und Werkstoff, 66(6), 439-446.

Kutnar, A. and Šernek, M. (2007) 'Densification of wood', Zbornik gozdarstva in lesarstva, (82), 53-62.

Kutnar, L., Eler, K. and Marinsek, A. (2015) 'Effects of different silvicultural measures on plant diversity - the case of the Illyrian Fagus sylvatica habitat type (Natura 2000)', iForest Biogeosciences and Forestry, 9(2), 318-324.

Lenth, C. A. and Kamke, F. A. (2001) 'Moisture dependent softening behavior of wood', Wood and Fiber Science, 33(3), 492-507.

Manfoumbi Boussougou, N., Nguyen, T. A., Angellier, N., Dubois, F., Ulmet, L. and Sauvat, N. (2014) 'Experimental and numerical aspects in diffusion process characterization in tropical species', European Journal of Environmental and Civil Engineering, 18(9), 963-982.

Mårtensson, A. and Thelandersson, S. (1990) 'Effect of moisture and mechanical loading on wooden materials', Wood Science and Technology, 24(3), 247-261.

Martin, P. and Vernay, M. (2016) Guide d'utilisation des bois africains éco-certifiés en Europe, [online], available: [accessed 
Medzegue, M. J. (2007) Etude comparative des bois d'Okoumé (Aucoumea Klaineana P.) issus des plantations et de la forêt naturelle: anatomie, durabilité naturelle, unpublished thesis Bordeaux 1.

Medzegue, M. J., Grelier, S., M'Batchi, B., Nziengui, M. and Stokes, A. (2007) 'Radial growth and characterization of juvenile and adult wood in plantation grown okoumé (Aucoumea klaineana Pierre) from Gabon', Annals of Forest Science, 64(8), 815-824.

Mertens, B., Minnemeyer, S., Ayenika Nsoyuni, L. and Steil, M. (2007) 'Atlas Forestier Interactif du Gabon', Version pilote. Document de synthèse. Rapport WRI, GFW.

Moutee, M. (2006) 'Modélisation du comportement mécanique du bois au cours du séchage'.

Moutee, M., Fafard, M., Fortin, Y. and Laghdir, A. (2005) 'Modeling the creep behavior of wood cantilever loaded at free end during drying', Wood and Fiber Science, 37(3), 521-534.

Moyne, C. and Martin, M. (1982) 'Etude experimentale du transfert simultane de chaleur et de masse au cours du sechage par contact sous vide d'un bois resineux', International Journal of Heat and Mass Transfer, 25(12), 1839-1848.

Mukudai, J. and Yata, S. (1986) 'Modeling and simulation of viscoelastic behavior (tensile strain) of wood under moisture change', Wood Science and Technology, 20(4), 335-348.

Nafa, Z. and Araar, M. (2003) 'Applied data for modeling the behavior in cyclic torsion of beams in glued-laminated wood: influence of amplitude', Journal of Wood Science, 49(1), 0036-0041.

Navi, P. and Girardet, F. (2000) 'Effects of thermo-hydro-mechanical treatment on the structure and properties of wood', Holzforschung, 54(3), 287-293.

Nguyen, S. T. T. (2014) Experimental characterization and thermo-mechanical modeling of cyclic behavior of polyethylene, unpublished thesis ISAE-ENSMA Ecole Nationale Supérieure de Mécanique et d'Aérotechique - Poitiers.

Odounga, B., Moutou Pitti, R., Toussaint, E. and Grédiac, M. (2018) 'Mode I fracture of tropical woods using grid method', Theoretical and Applied Fracture Mechanics, 95, 1-17.

Pambou Nziengui, C. F., Ikogou, S. and Moutou Pitti, R. (2017) 'Impact of cyclic compressive loading and moisture content on the mechanical behavior of Aucoumea Klaineana Pierre', Wood Material Science \& Engineering, 13(4), 190-196.

Pâques, L. (1996) 'Variabilité naturelle du mélèze. I. Mélèze d'Europe : bilan de 34 ans de test comparatif de provenances', Ann. For. Sci., 53(1), 51-67.

Peyrot, B. (2008) 'Incidences écologiques, anthropiques et paléoécologiques sur l'évolution des forêts du Gabon. Essai de synthèse', Les Cahiers d'Outre-Mer. Revue de géographie de Bordeaux, 61(241-242), 111-144.

Redman, A. L., Bailleres, H., Turner, I. and Perré, P. (2016) 'Characterisation of wood-water relationships and transverse anatomy and their relationship to drying degrade', Wood Science and Technology, 50(4), 739-757. 
Segovia, F., Blanchet, P., Laghdir, A. and Cloutier, A. (2013) 'Mechanical behaviour of sugar maple in cantilever bending under constant and variable relative humidity conditions', International Wood Products Journal, 4(4), 225-231. 